\title{
A MOSQUE IN A THOUSAND TEMPLE ISLAND: LOCAL WISDOM OF PEGAYAMAN MUSLIM VILLAGE IN PRESERVING HARMONY IN BALI
}

\author{
Mahmud Arif \\ UIN Sunan Kalijaga Yogyakarta \\ Jalan Laksda Adisucipto, Caturtunggal, Kec. Depok, Kabupaten Sleman, Daerah Istimewa Yogyakarta, Indonesia \\ E-mail: marifnurch@yahoo.co.id
}

\begin{abstract}
There are some scholars, such as Clifford Geertz, Geoffrey Robinson and Miquel Covarubbias who pay much attention to the patterns of the religious and cultural life of Balinese. They show various perspectives on Balinese religious and cultural lives, those that are generally closely related to Hinduism and tourism. For this reason, a study on the religious life of the Muslim communities in Bali is interesting because it represents various viewpoints while revealing another side of Balinese exoticism. Pegayaman Muslim village of Buleleng regency is an old village inhabited by Muslims amidst strong Hindu influences. This village is unique and recognized as one of the oldest Muslim villages in Bali. In general, the people in this village are able to live side by side peacefully with the adherents of other religions through local wisdom by building harmony with puri(castle), pura (temple), and Balinese customs, like actualization of Menyama Beraya in daily life and Sokok Base that are presented at procession of Maulid festival every year.
\end{abstract}

\section{Keywords:}

Muslim communities; Hinduism; Pegayaman village; Menyama Beraya; Balinese exoticism

\begin{abstract}
Abstrak
Banyak kalangan menaruh perhatian terhadap pola kehidupan keagamaan dan budaya masyarakat Bali, seperti Clifford Geertz, Geoffrey Robinson, dan Miquel Covarubbias. Tinjauan mereka mengenai kehidupan keagamaan dan budaya Bali tidaklah tunggal, kendati umumnya sarat balutan Hinduisme dan pariwisata. Dalam konteks itu, kajian mengenai kehidupan keagamaan masyarakat Muslim di Bali termasuk sesuatu yang menarik karena dapat merepresentasikan sudut pandang yang tidak tunggal tadi, sekaligus menguak sisi lain dari panorama Bali. Kampung Muslim Pegayaman Kab. Buleleng merupakan sebuah desa tua yang penduduknya beragama Islam, di tengah kuatnya pengaruh Hindu. Kampung ini memiliki keunikan tersendiri, yakni diakui sebagai salah satu kampung Muslim tertua di Bali. Secara umum, masyarakat di kampung tersebut mampu hidup berdampingan secara damai dengan penganut agama lain melalui kearifan lokal membangun harmoni dengan puri, pura, dan adat Bali, seperti pengejawantahan Menyama Beraya dalam kehidupan sehari-hari dan Sokok Base yang disajikan dalam prosesi festival Maulid pada setiap tahun.
\end{abstract}

Kata Kunci:

Masyarakat muslim; Hinduisme;Kampung Pegayaman; Menyama Beraya; Eksostisme Bali.

DOI: $10.15575 /$ jw.v4i1.4809

Received: June 17, 2019; Accepted: July 25, 2019; Published: July 30, 2019 


\section{A. INTRODUCTION}

From the gender perspective, one of the criticisms made by feminists is that Balinese people adhere to a strong patriarchal system that places men as the main figures in the social system. Besides that, social facts in the form of a caste system cause social stratification, including women ${ }^{1}$ made Bali have the socio-cultural distinction, either as a strength or a weakness, which has become the background of its various exoticism.

The Balinese are considered to have a cultural and natural exoticism that established as a leading tourist destination in Indonesia since a long time ago. Many nicknames are given to describe the exoticism, including The Paradise Island, The Island of God, dan The Mystical Island. ${ }^{2}$ Therefore, it is not excessive if Bali is displayed as a harmonious, exotic and apolitical area. $^{3}$ It is certainly very reasonable, considering that it is impossible that tourism in Bali is able to develop rapidly without being supported by the creation of security and peace. Thus, tourism has become an "ideology" the need for imaging harmony as it relates to shared economic interests. ${ }^{4}$ Tourism has caused a domino effect for stretching Balinese people's economy so they assume that anything that could interfere with their image and conflict of interests must be avoided immediately.

The existence of Bali which is predominantly Hindu with "a thousand temples" makes this God'sIsland unique. According to Clifford Geertz, the practice of Balinese religious offerings and rituals show

\footnotetext{
${ }^{1}$ Wening Udasmoro, Dari Doing Ke Undoing Gender: Teori Dan Praktik Dalam Kajian Feminisme (Yogyakarta: Gadjah Mada University Press, 2017), 184.

${ }^{2}$ Yudhis M. Burhanuddin, Bali Yang Hilang: Pendatang, Islam Dan Etnisitas Di Bali (Yogyakarta: Impulse Kanisius, 2008), 51.

${ }^{3}$ R. Siti Zuhro et al., Demokrasi Lokal: Perubahan Dan Kesinambungan Nilai-Nilai Budaya Politik Lokal Di Jawa Timur, Sumatera Barat, Sulawesi Selatan Dan Bali (Yogyakarta: Ombak, 2009), 202.

${ }^{4}$ Burhanuddin, Bali Yang Hilang: Pendatang, Islam Dan Etnisitas Di Bali, 202.
}

that they are more attentive to practicing it rather than thinking about it. ${ }^{5}$ Therefore, it is not strange if many people perceive Balinese are Hindus, and their religious rituals procession caused its own charm for tourists. This perception is not entirely true, because, many Balinese are non-Hindus, either indigenous population of Bali or migrants. As a miniature of Indonesia, ${ }^{6}$ Bali is one of the "best" regions to represent diversity. Naturally, many Indonesianist scholars such as Clifford Geertz, Geoffrey Robinson, and Miquel Covarubbias who paid much attention to the patterns of the religious and cultural life of the Balinese. The Indonesianist perspective on Balinese religious and cultural life is not singular. On the one hand, there are people who tend to see the exoticism of Bali with Hinduism, natural beauty and rich culture. On the other hand, there are people who tend to see the historical dynamic of Bali which is full of tensions and conflicts. Moreover, there are also experts who see the exoticism of Bali from the excesses caused by modernization. ${ }^{7}$

The variety of opinions among experts regarding the relationship between Bali and Hinduism as "indigenous" religion and majority or Balinese exoticism is certainly interesting to be discussed. After the Bali bombing, there was a striking socio-cultural dynamic in Balinese people's lives. Moreover, there are people who call "Lost Bali" because there are many serious problems relates to life order and patterns of socio-religious relations. It is the background ofAjeg Balimovement, a massive movement that wants to preserve Balinese culture either at the individual level, or the cultural environment or cultural process as a form of public concern about serious problems affected by people's behavior.

${ }^{5}$ Clifford Geertz, Tafsir Kebudayaan \& Agama (Yogyakarta: Kanisius, 1992), 129-130.

${ }^{6}$ Bernard A. Risakotta, Mengelola Keragaman Di Indonesia: Agama Dan Isu-Isu Globalisasi, Kekerasan, Gender, Dan Bencana Di Indonesia, Trans. Gunawan Admiranto dkk (Bandung: Mizan, 2015), 23.

${ }^{7}$ Nengah Bawa Atmadja, Ajeg Bali: Gerakan, Identitas Kultural, Dan Globalisasi (Yogyakarta: LKiS, 2013). 

of Pegayaman Muslim Village in Preserving Harmony in Bali

Bali, which has been known to be safe, and peaceful, nowadays, experiencing cultural slack and slowly tends to move away from its valuable culture. In the context of the elections, for example, it occurs the issue of ethnicity, religion, race, and intergroup (SARA) for campaign purposes, and has triggered conflict and violence. The public awareness of diversity as the basis of the spirit of nationalism crushed by ideological or pragmatic interests. It is regrettable that the use of SARA issues and the rise of violent conflicts with SARA nuances emerged in various regions ${ }^{8}$ that involve religiousor community leaders. It ruined the unity and harmony of citizens as well as the integrity of the Republic of Indonesia. The violent conflict based on SARA clearly in contrast with the spirit of nationalism that has long been woven and embodied in the local wisdom of Bali, Tri Hita Karana, which is maintaining good relations with God, fellow humans, and nature. ${ }^{9}$

Elizabeth K. Nottingham, an expert in Sociology of Religion, argued that social and psychological functions played by religion proved to be fundamental. ${ }^{10}$ No wonder that religion is considered as one of the factors that have a profound influence on people's lives ${ }^{11}$ and the formation of their cultural traditions. Thus, religion plays an important role in public space, social interaction, and modernity. Globalization does not necessarily lead that religion will be marginalized. ${ }^{12}$

\footnotetext{
${ }^{8}$ Antara, "Survei LIPI: Isu SARA Membesar Karena Dikapitalisasi Elit Politik," Antara News, accessed August 12, 2018, https://www.antaranews.com/berita/734208/survei-lipiisu-sara-membesar-karena-dikapitalisasi-elit-politik.

${ }^{9}$ Zuhro et al., Demokrasi Lokal: Perubahan Dan Kesinambungan Nilai-Nilai Budaya Politik Lokal Di Jawa Timur, Sumatera Barat, Sulawesi Selatan Dan Bali, 208.

${ }^{10}$ Elizabeth K. Nottingham, Agama Dan Masyarakat, trans. Abdul Muis Naharong (Jakarta: Rajawali Press, 1997).

${ }^{11}$ Meredith B. McGuire, Religion: The Social Context (California: Wadsworth Publishing, 1992), 3.

${ }^{12}$ Mujiburrahman, Mengindonesiakan Islam (Yogyakarta: Pustaka Pelajar, 2008), 48; See also
}

Pegayaman Muslim village in Bulelengdistrictis a village with a majority Muslim population ${ }^{13}$ amidst the strong siege of Hindu influence. The village has its own uniqueness. Pegayaman village is one of the oldest Muslim villages in Bali which has a historical link with Solo-Javanese Pedaleman and thick Balinese acculturation. Pegayaman village is divided into several hamlets where the community adhere to a different religion. The majority of residents of Pegayaman village are Muslim and surrounded by the Sukasada subdistrict area which the community adheres to Hinduism. Both religious adherent groups have a place of worship in a nearby location, and they feel free in carrying out their respective religious teachings.

This article employs a qualitative method examining a pluralistic community life. Its citizens are identified as active involvement in building harmony, namely Muslim communities in Pegayaman village, Buleleng District, Bali province. This study utilizes the theory of socio-cultural studies from Bodgan and Biklen whose assumption stated that the world is not "something that can be known directly,"14 it depends on the researcher's perspective. As a form of Sociocultural studies, this study assumes that (1) all social relations are influenced by certain factors that need to be explained in a specific context, and (2) all research comes from theoretical understanding. Data was collected from interviewing informants: religious leaders, community leaders and citizens from Pegayaman Muslim village as research subjects, observation, and documentation.

The study of local wisdom or culture of Balinese has been done by many researchers.

Bachtiar Effendy, Masyarakat, Agama Dan Pluralisme Keagamaan (Yogyakarta: Galang Press, 2001) 21.

${ }^{13}$ Moh Mashur Abadi, "Pesantren Desa Pegayaman, Meleburnya Jagat Bali Dalam Kearifan Islam," KARSA: Journal of Social and Islamic Culture 20, no. 1 (2012): 152-64.

${ }^{14}$ William J. Potter, An Analysis of Thinking and Research About Qualitative Methods (New Jersey: Lawrence Erlbaum Association, 1996), 109-110. 
Suprapto has written the book entitled Semerbak Dupa di Pulau Seribu Masjid. ${ }^{15}$ This book, derived from his dissertation, describes the harmonious life of the Hindu minority in the middle of the Muslim majority in Lombok. Both groups of different religions and cultures are able to live side by side peacefully, and the Hindu minority group has the freedom to practice their religious teaching.

Ismail Suardi-Wekke wrote about Sasi Masjid dan Adat: Praktik Konservasi Lingkungan Masyarakat Minoritas Muslim Raja Ampat. ${ }^{16}$ It is originally the result of research on the local wisdom of Raja Ampat Muslim minority community in preserving the environment, even the mosque became an institution that holds the authority to regulate the management of an environment called sasi masjid. Celebrations of the earth and sea products are carried out together by both the mosque community and the church community.

Other research conducted by Indriana Kartini on Dinamika Kehidupan Minoritas Muslim di Bali, ${ }^{17}$ contains the research of Muslim minority community in Bali. It explained multiculturalism in Bali which is at least demonstrated by the long history of the existence of the Muslim minority there. Unfortunately, it has not received much attention yet from many studies about Bali. Whereas the acculturation of Islam, Hinduism, and Bali have produced cultural richness and local wisdom which is not mere "Hinduismcentric." In the acculturation of Islam, Hinduism and Bali should be seen in both ways Muslim minority and Hindu majority.

Ari Dwipayana (ed.) compiled articles called Bulan Sabit di Pulau Dewata: Jejak

\footnotetext{
${ }^{15}$ Suprapto, Semerbak Dupa Di Pulau Seribu Masjid (Jakarta: Kencana, 2010).

${ }^{16}$ Ismail Suardi-Wekke, "Sasi Masjid Dan Adat: Praktik Konservasi Lingkungan Masyarakat Minoritas Muslim Raja Ampat," Al-Tahrir: Jurnal Pemikiran Islam 15, no. 1 (2015): 1-20.

${ }^{17}$ Indriana Kartini, "Dinamika Kehidupan Minoritas Muslim Di Bali," Jurnal Masyarakat Indonesia 37, no. 2 (2011): 115-45.
}

Kampung Kusamba-Bali. ${ }^{18}$ The monograph book from field study result analyzes the history of Islamic villages, renegotiates Islamic villages in Hindu adherents, tolerance, and tension as the forms of biodiversity management, particularly in Kusamba-Bali village. In short, the results of this monograph research explain the identity of Muslims in the Hindu land of Bali, as well as reveal patterns of Muslim-Hindu relations.

Deni Miharja conducted research on Adat, Budaya dan Agama Lokal: Studi Gerakan Ajeg Bali Hindu Bali. ${ }^{19}$ This research elaborates the Balinese movement as an articulation of efforts to preserve the values and traditions of Balinese ancestors, and a "local religion" that its teachings preserved traditional values and could protect it from the influence of foreign cultures.

A. Muchaddam Fahham reported in Dinamika Hubungan Antarumat Beragama: Pola Hubungan Muslim dan Hindu di Bali ${ }^{20}$ about the harmonious relations among religious communities in Bali Province which is ranked the second-best nationally. However, it does not mean that the relationship among religious communities in Pulau Dewata is running well. In reality, in addition to finding associative relationship patterns -that lead to cooperation, accommodation and toleranceundeniably also found patterns of dissociative relationships that lead to competition and conflict. The article described more aboutthe support associative and dissociative relation patterns among Balinese Muslims.

${ }^{18}$ I Gde Parimartha, Ida Bagus Gde Putra, and Luh Pt. Kusuma Ririen, Bulan Sabit Di Pulau Dewata: Jejak Kampung Islam Kusamba-Bali, ed. AAGN. Ari Dwipayana (Yogyakarta: CRCS UGM, 2012).

${ }^{19}$ Deni Miharja, “Adat, Budaya Dan Agama Lokal: Studi Gerakan Ajeg Bali Hindu Bali," Kalam: Jurnal Studi Agama Dan Pemikiran Islam 7, no. 1 (2013): 53 78.

${ }^{20}$ A. Muchaddam Fahham, "Dinamika Hubungan Antarumat Beragama: Pola Hubungan Muslim Dan Hindu Di Bali," Aspirasi: Jurnal Masalah-Masalah Sosial 9, no. 1 (2018): 65-84. 


\section{B. RESULT AND DISCUSSION 1. Bali and Islam}

Bali's exoticism makes its own charm, as shown by the large number of tourists who come to travel, the number of outsiders who live to earn a fortune, and many scientists who consider Bali as the object of study. ${ }^{21}$ In addition to the exoticism of nature and culture as a famous tourist destination, until now Bali is also widely known as one of the regions in Indonesia where the Hindusmajority lives. Therefore, Bali and Hinduism have become two "cultural" entities that are united and inseparable; Bali is considered synonymous with Hinduism, and Hinduism has also been a source of forming the main religious-cultural identity of Balinese society. As a result, it is argued that some experts claim that Balinese culture is a religious culture, ${ }^{22}$ which is a culture that originates from Hinduism.

The close relationship between Bali and Hinduism is strengthened by the belief of people in Bali that Gunung Agung and Pura Besakih are the centers of Bali island. ${ }^{23}$ In addition, the existence of community stratification(castanization) in Bali based on the concept of catur warna or catur warga. These are the Brahmin group who has the highest status, then Ksatryagroup, Weisya group and Sudra group who has the lowest status. It also confirms the close relationship between Bali and Hinduism. Historically, the links between Bali and Hinduism were formed through a long historical process. Bali received a strong influence from the Majapahit Kingdom in Java. When Majapahit was at its glory, Bali became one of the important areas with the center of power which later became the Kingdom of Gelgel covered an extending

\footnotetext{
${ }^{21}$ Martin Ramstedt, Kegalauan Identitas: Agama, Etnisitas Pada Masa Pascaorde Baru (Jakarta: Grasindo, 2011), 41-42.

${ }^{22}$ I Nyoman Suryawan, Genealogi Kekerasan Dan Pergolakan Subaltern: Bara Di Bali Utara (Jakarta: Kencana, 2010), 284.

${ }^{23}$ AAG. Putra Agung, Peralihan Sistem Birokrasi Dari Tradisional Ke Kolonial (Yogyakarta: Pustaka Pelajar, 2009), 11.
}

area to Lombok, Sumbawa and Blambangan. ${ }^{24}$ This kingdom is getting stronger as the weakening of Majapahit. This was confirmed by the results of an interview with Nasrulloh, one of the Muslim leaders of Gelgel Village, who said, "The history of the formation of Gelgel Muslim village began with forty Muslim soldiers from Majapahit who were assigned to guard King Gelgel. Then as a form of appreciation of King Gelgel, they were then given the land of the fief to be inhabited with special autonomy." 25

Although the relationship between Bali and Hinduism is so strong, in its history, Bali has never closed itself to the presence of other communities. It is thought to be one of the factors why Bali remains Hindu in the midst of the rapidly growing siege of Islam in Java and Lombok because Bali has never been significantly "anti-Islamic." Naturally, Islam ruled after the collapse of Majapahit did not consider Bali with its Hinduism as a serious threat that had to be subdued. In addition, the Hindu kingdom in Bali also implemented a "friendly" defense strategy through the establishment of Muslim community bases around the royal center, as seen in Puri Karangasem surrounded by Muslim villages. From here the peaceful coexistence of Muslims and Hindu communities in Bali began. For Balinese Hindus, the Muslim community is considered asnyama selam or Islamic brother. ${ }^{26}$ To maintain harmony in living together, there is ngejot which means shares food from Muslim brothers to Hindu brothers and vice versa on certain holidays which become social capital in building interethnic and interreligious solidarity. ${ }^{27}$

There is an interesting analysis regarding why Bali remains Hindu, either niskala or sekala perspective. The first perspective tends

\footnotetext{
${ }^{24}$ AAG. Putra Agung, Peralihan Sistem Birokrasi, 42.

${ }^{25}$ Nasrulloh, interview by Mahmud Arif, Gelgel Village, on October 4, 2018.

${ }^{26}$ Sahidin, interview by Mahmud Arif, Gelgel Village, on October 5, 2018.

${ }^{27}$ Atmadja, Ajeg Bali: Gerakan, Identitas Kultural, Dan Globalisasi, 341.
} 
to explain fromthe metaphysical aspect that Hindu figures such as Danghyang Nirartha have made magical fortresses across the coast of Bali that cannot be penetrated by outside invaders. $^{28}$ Meanwhile, the second perspective, which makes more sense, explains from the historical aspect that Majapahit began to lose its dominance. Most of its territory experienced Islamization but remained with maritime culture. Unlike Java, Bali does not have a major trading port, nor spices are significantly grown in Bali, and the people are still agrarian so that the island is not included in the silk road traversed by Muslim traders and preachers. Moreover, the arrival of the Dutch caused the attention of the Islamic Mataram kingdom split, so there was no time to expand power to Bali.

Some experts view that Islam established in Bali is quite unique. Considering in its history, the Muslim community who came to this island obtained special permission to live permanently or even because of requests for a direct assignment from puri/palace of the Hindu Balinese kingdom. It is natural if they then inhabit certain areas, have a close relationship with the castle, and do not expand the territory/influence and mission activities. On the one hand, it is the main capital of the Muslim community to be accepted by the Balinese Hindu community. But on the other hand, the spread of Islam became localized because it is only developed in a certain area. This phenomenon is called the political quarantine of rulers in various Hindu kingdoms in Bali against the Muslim population at that time. ${ }^{29}$

The spreading of Islam by the saints culturally also took place in Bali. There are several prominent figures who spread Islam in Bali, known as Walipitu. They are Shaykh Chamdoen Khoirussoleh or Pangeran Mas

\footnotetext{
${ }^{28}$ Nengah Bawa Atmadja, Genealogi Keruntuhan Majapahit: Islamisasi, Toleransi, Dan Pemertahanan Agama Hindu Di Bali (Yogyakarta: Pustaka Pelajar, 2010).

${ }^{29}$ Nengah Bawa Atmadja, Genealogi Keruntuhan Majapahit.
}

Sepuh, son of King Mengwi VII (Cokorda I), the descent of a mother who came from Blambangan or Banyuwangi. His grave is on the beach of Seseh Badung Bali; Habib Umar bin Maulana Yusuf al-Maghribi whose grave is located on one of the hills in Bedugul Tabanan; Habib Ali bin Abu Bakar al-Hamid who spread Islam in Klungkung region and had been appointed as a translator and linguist of Gelgel kingdom; Shaykh Maulana Yusuf al-Maghribi who spread Islam in Karangasem region; Shaykh Abdul Qodir Muhammad, who spread Islam in Buleleng region and have been a student of Sunan Gunung Djati.

The process of an Islamicmissionary endeavor takes place in a harmonious atmosphere, without significant friction between Muslims and Hindus. Depends on the indications of some experts, there are at least four important factors that underlie it. First, the followers of Hinduism are Balinese with their distinctive mindset and culture, not Hinduism set in India. It is the same as adherents of Islam who are typically indigenous Indonesian and unfamiliar with Arabic culture. With this style, Muslims and Hindus in Bali are also able to establish harmony. Second, Muslims who come to Bali tend to develop the symbols of Islam in a persuasive manner. Third, during the royal era, Bali was never involved in a conflict with Javanese kings. Fourth, Balinese Hinduism and Islam have similarities in their cultural perspectives, such as maintaining harmony with nature. ${ }^{30}$

\section{Wisdom Values of Pegayaman Muslim Community}

The establishment of Pegayaman Muslim village has been going on for hundreds of years ago and still exists until now. Pegayaman village is located between the hills of North Bali with a height of about 500 meters above sea level which is part of

\footnotetext{
${ }^{30}$ M. Abdul. Karim, "Toleransi UmaT Beragama Di Desa Loloan, JemBrana, Bali (Ditinjau Dari Perspektif Sejarah)," Analisis: Jurnal Studi Keislaman 16, no. 1 (2016): 1-32.
} 
Sukasada subdistrict, Buleleng district. This village is divided into 5 hamlets (banjars). Those are Banjar Dauh Margi, Dangin Margi, Kubu, Kubu Lebah, and Amerta Sari. Pegayaman Village has an area of $15.84 \mathrm{~km} 2$ with a population of more than 2000 households. In the north, Pegayaman borders Pegadungan village, in the east borders Silangjana village, in the south borders Pancasari village, and in the west borders Padangbulia village and Gitgit village. Pegayaman residents communicate in the Balinese language that categorized refine. In addition to the language of daily communication, they also adhere to Balinese culture so deeply as can be seen in the use of unique Balinese names. The consistency in giving their child's name Wayan for the first child, Nengah for the second child, Nyoman for the third child, and Ketut for the fourth child. Not surprisingly, many Muslims in Pegayaman named such as Nengah Sururudin, Wayan Suharto, Nyoman Haromain, and Ketut Ibrahim.

The name Pegayaman is derived from the word "gayam" (or gatep in Balinese). It is a kind of hard fruit whose fruit is delicious to be eaten. ${ }^{31}$ It is also believed comes from the word gayaman which became the name of a powerful dagger (keris)used as a weapon during Mataram Islamic Javanese kingdom under the authority of Paku Buwono I in remembrance of the Pegayaman village community ancestors who first came to Bali from Mataram. This was reinforced by Babad Buleleng that the ancestors of the Pegayaman community were known as Solo Pedaleman, and by the indigenous Balinese people at that time, they were called nyame selam (brothers of Islam). Historical analysis of the ancestors of the Pegayaman community originating from Mataram was when the Majapahit kingdom collapsed, in Bali, there was Hindu Gelgel (Klungkung) kingdom which still prevailed in the territory of Lombok and Sumbawa. At that time, Raja Gelgel led troops to seize
Blambangan (Banyuwangi), which was under the rule of Mataram. On this second expedition, the Gelgel army succeeded in winning. To avoid further warfare, there was a truce between the Gelgel kingdom and Mataram kingdom. As a form of peace, the King of Mataram sent a messenger to hand over an elephant gift to Raja Gelgel as a vehicle. The messenger sent at once was assigned to be an elephant handler and given permission to settle in Banjar Jawa Singaraja (Buleleng), which is located nearby Banjar Petak and Banjar Peguyangan. In the Balinese language, Petak means cage and Peguyangan means a place where elephants are bathed or where they lie down in muddy water.

The arrival of Mataram envoy was considered to carry a peaceful mission, there was no longer any hostility or war. On the occasion of conducting inspections to Banjar Jawa Singaraja, the King offered them to move to the south while also being assigned to be the "fortress" of the kingdom from south attacks. They agreed to the King's offer and were given the freedom to take the area of Palemahan (yard) in a forest area flanked by two hills and two large rivers, which became the forerunner to Pegayaman village. They mingle with the native Balinese, even marriage and cultural acculturation. A few decades later, some people from the Bugis tribe of Sultan Hasanudin Makassar expeditionary army came to this area where their ship was stranded on the coast of Buleleng. Religious equality makes it easy for them to blend in with Pegayaman's ancestors. Therefore, the pivot axis of the Pegayaman people is Javanese-Bali-Bugis. The religious understanding adopted by the majority of the community is "traditionalist" Islam as seen in religious activities of the community and routine schedule of Safinatussalam Pegayaman Jami Mosque, such as Tarhim to remind residents that the time for the dawn is before dawn during Ramadan, Tarawih prayer at 20 rekaat, Barzanji, etc. Inside the mosque,

\footnotetext{
${ }^{31}$ WayanSuharto, interview by Mahmud Arif, Gelgel Village, on October 5, 2018.
} 
there are very large kentongan, drum, and tall towers. ${ }^{32}$

The view of Pegayaman's ancestors from Solo is still justified by the people there until now. To connect the friendship with the ancestral region, some Pegayaman figures had visited Surakarta palace. The visit was intended to establish cooperation and at the same time build a shared historical awareness regarding genealogical links between Pegayaman people and Surakarta Palace. Building historical awareness of origin ancestral links with Surakarta palace is needed to strengthen the social memory of the current generation of Pegayaman people.

During this time, the Pegayaman community art group has been actively involved in Buleleng Festival (Bufest) and Bali Arts Festival (Pesta Kesenian Bali-PKB) which carry the spirit of pluralism. The logo and art tools of the Sekee Burdah Burak Pegayaman group are very rich with the nuances of Islamic and Balinese acculturation. Through the slogan Siap Menghidupkan dan Mengabadikan Api Kedamaian Dengan Konsep Hidup "Menyama Beraya" (friendship in diversity), the art groups intend to articulate the spirit of brotherhood among Balinese fellow. Pegayaman Islam is not an exclusive Islam, but rather Islam-Bali which developed through a long process of Islamic Balinization. Art is one of the devices of the Islamic balinization process that is able to unite the diversity of society. Because of it, one of Pegayaman community leaders was not worried about arranging his daughter's Puspanjali dance, as part of Balinese dance, while still wearing a hijab. ${ }^{33}$ Her expertise in Balinese dancing and her academic achievements have given the daughter an opportunity to do a comparative study in Japan with other representatives from Bali.

The existence of believed Jerontuan religious tourism site by the community as a

\footnotetext{
${ }^{32}$ WayanSuharto, interview by Mahmud Arif, Gelgel Village, on October 5, 2018.

${ }^{33}$ Suharto, Wayan, interview by Mahmud Arif, Gelgel Village, on October 5, 2018.
}

gathering place for saints is a historical proof that the development of Islam has been happening for hundreds of years ago. Many Muslim communities make pilgrimages to pray and hold salvation on the site when they have the intention to be granted by God, or hold a ceremony for received blessings. In addition to the Jerontuan site, other historical evidence is the pulpit of Safinatussalam mosque which is hundreds of years old. The Jerontuan site and the jami mosque with their ancient pulpit confirm the coexistence between Pegayaman Muslims and surrounding Hindus going well. The ancient site of the Muslim community has been preserved until now because it was never disturbed or damaged by Hindus.

The knot of togetherness proven effective in realizing social harmony and being positively accepted as the cultural heritage of the local community. This practice is considered sources of local wisdom formation to mark (1) the identity of a community, (2) adhesive elements across citizens, (3) inner awareness in order not to "force", (4) the togetherness of a community, (5) the mindset modification and interactive relationships on a common ground, the process of appreciation and participation; and avoidance disintegration. ${ }^{34}$ Even from the results of cultural studies, in several regions in Indonesia such as the Bedouin community in Banten and Maluku community, local wisdom has proven useful in maintaining the balance of nature so that natural resource management does not damage the environment. ${ }^{35}$

The other side of togetherness knot that is still preserved is the commemoration of Prophet's Birthday which the formation of the committee and it's preparations made three months earlier. ${ }^{36}$ According to the informant, "In organizing Prophet's Birthday, the

\footnotetext{
${ }^{34}$ Suprapto, Semerbak Dupa Di Pulau Seribu Masjid, 60-61.

${ }^{35}$ Alo Liliweri, Pengantar Studi Kebudayaan (Bandung: Nusa Media, 2014), 227-236.

${ }^{36}$ Suharto, Wayan, interview by Mahmud Arif, Gelgel Village, on October 5, 2018.
} 
committee had been formed three months before. The prepared procession and Ubo Rampe are rich with Islamic acculturation and Balinese culture. Ubo Rampe Sokok is a sort of gift for ritual purpose consisting of an egg prick that is placed on a Pajegan (banana stem), a series of bamboo decorated with flowers and fruits underneath, similar to the ceremonial at the temple for Hindu society." ${ }^{17}$ The procession of Prophet's birthday celebration was enlivened by silat dance, Sekaa Hadrah, and accompaniment of tambourine performance. All residents from various communities, including local government representatives, castle families, Hindu figures and other local village government officials, were invited to attend. The commemoration of Prophet's Birthday becomes a place of togetherness and performing arts that are rich with Balinese nuance without any social barriers. The existence of art and entertainment elements makes the event not only create an attraction for Muslims, but also for other community members.

The commemoration of Prophet's Birthday is proof that the existence of Muslim residents of Pegayaman village has contributed to surrounding community culture, especially in Sukasada sub-district, which is predominantly Hindu. The long history of Islamization in Pegayaman village through constructive and tolerant penetration leaves cultural heritage in a harmonious life with adherence to other religions. It has inspired Muslim citizens of Pegayaman village to successfully carry out the expected roles in order to knit togetherness and harmony of life, either among Muslims or Muslims with other religious adherence. The tradition of Prophet's Birthday commemoration becomes part of social capital which is sourced from local wisdom in caring for harmony in the midst of diversity. It is not only the internal cohesion of religious communities that needs to be strengthened but also external cohesion through the

\footnotetext{
${ }^{37}$ Suharto, Wayan, interview by Mahmud Arif, Gelgel Village, on October 5, 2018.
}

development of mutual respect that is able to foster affinity among members of the interfaith community.

\section{The actualization of Wisdom Values in Building Harmony}

The establishment of Pegayaman Muslim village has a long history that it is called "the oldest Muslim village" in Bali. One historical record mentions that the Muslim community of Pegayaman village is a descendant of Javanese and Bugis who had come to Bali several centuries ago. ${ }^{38}$ The location of Pegayaman village is around $87 \mathrm{~km}$ from Denpasar city and $9 \mathrm{~km}$ from Singaraja city (Buleleng). One of the leading Islamic education institutions in this village is the AlIman Islamic Boarding School and Miftahul Ulum madrasa which is located close to Jami 'Safinatussalam Pegayaman mosque complex. Some relics of Islamic history are still well preserved, such as wood carvings and the pulpit at Safinatussalam Mosque which is allegedly more than 200 years old. This mosque is the only mosque in Pegayaman village which was founded by Kumpi Kyai Yahya in 1639 and became the center of Islamic development in Bali. Kumpi, the name attached to Kyai Yahya, is a high social title for certain people. The mosque has undergone several renovations so that the architecture is no longer what it was. In 1986, a renovation of the Safinatussalam mosque was carried out by involving a number of artisans and workers from the Hindu community. In addition to Safinatussalam Mosque, around Pegayaman there are approximately 19 mushala (santreng).

Not only as of the oldest mosque, Safinatussalam is also the largest and "independent" mosque because it has productive assets in the form of waqf land and yards that are well managed and capable of producing an added value of not less than 100

\footnotetext{
${ }^{38}$ Suharto, Wayan, interview by Mahmud Arif, Gelgel Village, on October 5, 2018.
} 
million per year. ${ }^{39}$ The added value (profit) of the productive assets and funds that are collected regularly from the congregation become an important financial source for financing operational and development needs. Naturally, if the mosque is able to carry out various religious activities in a wellprogrammed, meet the needs of its facilities adequately, and carry out its role as a center for the development of Islam and society.

Muslim History of Pegayaman village is famous for its social history that full of struggle and courage. Because of a long time ago, Pegayamanvillagewas still famous for its very haunted wilderness. Then by some of the Taruna Goak Muslim troops from Javanese and Bugis ethnic groups, who became the core warriors of Raja Panji Sakti, the forest was encroached to be converted into villages. They are the ancestors of Pegayaman that in Babad Buleleng are called Tindih (defenders) because they have been credited in protecting the Bulelengkingdom and dedicating themselves to the king. Some of them married native Balinese women, formed families, and produced a unique social and cultural system that was characterized by "Islam-Bali."

The history of the Pegayaman Muslim community's harmonious relationship with the castle (palace) continues till today. It is shown by the hospitality relationship that continues by inviting and attending each other when important events are held in Pegayaman, such as the celebration of prophet's Birthday, or that held in Puri (palace), such as marriages of members of the royal family. The longstanding track record of good relations is the cultural capital of both parties for mutual respect, mutual trust, and mutual understanding. Historical facts show that although Pegayaman community's ancestors were Muslim, they still showed a high level of loyalty in carrying out the duties and beliefs of the Hindu king.

\footnotetext{
${ }^{39}$ Suharto, Wayan, interview by Mahmud Arif, Gelgel Village, on October 5, 2018.
}

Persistence in adhering to the teachings of Islam does not prevent them from continuing to serve the Hindu kingdom, mingle with the community, and take part in fostering harmony together. This attitude actually makes the castle (palace; kingdom) feel reluctant and give high respect and called them asNyame Selam term (the brother of Islam). It is used by Hindus to refer to Muslims. The term clearly shows the meaning of a strong social bond between Hindus and Muslims. In the context of social interaction, a designation is considered to have psychological and sociological content. Psychological content is the designation was born from the atmosphere of the mysticism of the Hindu community who feel a close and mutual affinity with Muslim citizens, without any prejudice even hatred. Its sociological content, as a minority, Muslims obtain recognition and position that are equal to those of Hindumajority without any discrimination or segregation.

By its historical background, the relation of the Muslim minority and Hindu majority in Bali seems to have different characteristics from the Dani Muslim community in Jayawijaya Papua. As a minority group, the Dani Muslim community displays its uniqueness in identifying themselves as adherents of Islam. ${ }^{40}$ They still maintain Papuan tradition which is partly contradictory to the basic teachings of Islam so that it looks "different" from other Muslim communities. Besides, they are also different from the majority of Papuans who are Christians. The Islamic style of Dani Muslim community is full of challenges from other Muslim communities, because they are considered not fully Muslim, and also from the majority of Papuans who are Christian. However, the Dani Muslim community feels proud of their Islam and continues to love the Papuan tradition.

\footnotetext{
${ }^{40}$ Ade Yamin, "Menjadi Muslim Papua: Perjuangan Komunitas Dani Muslim Di Lembah Bailiem" (UMY, 2019).
} 
The existence of the Muslim community in Pegayaman village has acculturated in such ways to Balinese culture so that they also deserve to be called Balinese or Balinese Malay. Balinese culture becomes more colorful because of acculturation. So, Balinese culture is identical not only with Hinduism but also with other religions such as Islam in Balinese cultural mosaics without diminishing the value of "authenticity." The acculturation process leads to selective integration, in which the Muslim community adapts to local Balinese culture, blends in social life without compromising the principle aspects of the believes held, still upholds pluralism, and is proactive in knitting togetherness. Through acculturation with selective integration patterns, the Muslim community of Pegayaman village is able to separate Bali and Hinduism, between the cultural and religious ones, therefore they do not simply draw a dividing line to separate Islam and Bali.

The Muslim community is able to absorb and concoct Balinese culture, then present Islam which is laden with the locality. Islamic acculturation in the context of Balinese culture is a creative step to absorb and mix local culture, then articulate a friendly Islam with "local traditions." Thus, the acculturation process is needed as a foothold to articulate Islam so that the message of the teachings presented worthy to be seen as part of the original culture. Cultural acculturation is shown by Pegayaman Muslim acceptance such as dance, clothing and Balinese names. For Muslims, wearing a Balinese costume in performing arts has a dual function: appreciating Balinese custom and presenting Islam in the tradition of being able to tighten the relationship between Muslim and nonMuslim Balinese citizens.

\section{Problems of Pegayaman Muslim Community in Building Harmony}

Identity is one of the main topics in plural social life. It is found the use of many symbols in public spaces that are actually intended to establish self/group identity in order to build internal cohesion and solidarity, as well as to make messages about the existence of self/groups for outsiders (external). As if it has become a basic need in social life. Everyone has the need to classify themselves to be "us" and "them" 41 to underlie the social meaning of each identity. Sociologically, the formation of a single identity can consist of religion, profession, association, caste, political parties, and others.

The use of certain religious symbols in pluralistic public spaces is very vulnerable to negative external reactions. ${ }^{42}$ As an example, strong comment from one of the local representative (DPD) Bali member I Gusti Ngurah Arya Wedakarna on the entry of sharia banking along with the blame that certain parties have the same view on terrorist behind sharia branding brought to Bali. ${ }^{43}$ Appeared among the Muslim community in Bali related to the provocative claims of DPD members because it can trigger the friction between Hindus and Muslims. Taidin, a Muslim youth leader from Loloan village, fully agreed that Arya Wedakarna's prejudices often motivates cross-regional Muslim communities' consolidation in Bali to fight for the election of DPD candidates who is Muslim, ${ }^{44}$ despite choosing candidates to run aground in the contestation on the April 17, 2019 elections.

Thinking way of binary opposition or Rwa Bhineda, which is widely adhered to by the Balinese people, ${ }^{45}$ is considered to have the potential to encourage ideological meaning. It means that identity is no longer understood as

\footnotetext{
${ }^{41}$ Paulus Wirutomo, Sistem Sosial Indonesia (Jakarta: UI Press, 2012), 3.

${ }^{42}$ Sumanto Al Qurtuby, "Sejarah Politik Politisasi Agama Dan Dampaknya Di Indonesia," MAARIF Journal 13, no. 2 (2018): 43-54.

${ }^{43}$ Republika, "Arya Wedakarna Curiga Masuknya Perbankan Syariah Di Bali," Republika, accessed October 16, 2018, https://www.republika.co.id/berita/dunia-islam/islamnusantara/14/08/26/nawgoo-arya-wedakarna-curigamasuknya-perbankan-syariah-di-bali.

${ }^{44}$ Taidin, interview by Mahmud Arif, Gelgel Village, on October 5, 2018.

${ }^{45}$ Atmadja, Ajeg Bali: Gerakan, Identitas Kultural, Dan Globalisasi, 8-10.
} 
a liquid group marker, but rather as a rigid media grouping citizens and demand supreme loyalty. In this context, the imposition of certain identity symbols, such as the case of "Pembulelengan," can be a serious threat to harmony among people of different identities. Pembulelengan case is considered a massive "Golkar" movement against the PDIP loyalist community base, triggers a bloody clash on October 26, 2003, in Petubah village Buleleng which caused death in the brawl between PDIP supporters and Golkar supporters. ${ }^{46}$ Similar mass actions were also found in other areas such as Badung, Karangasem, Gianyar, Denpasar, and Jembrana. ${ }^{47}$

In line with this case, polemic and disagreement between Muslims and some Hindus that had occurred regarding the construction of Al-Qur'an Education Park and majelis taklim, for example, were forms of identity conflict. The intention of the Muslim community to build a landfill site and majelis taklim which has been given permission by the local government must be hampered to be built because it does not have a permit from Adat village (Pakraman) because it is considered in customary land. ${ }^{48}$ In many cases, Adat villages (Pakraman) has more authority than village officers. Indigenous village (Pakraman), as one of the joints of growing Balinese Ajeg movement, ${ }^{49}$ is not infrequently considered likely to lead to Hindu Ajeg which becomes seeds of Hindu fundamentalism. Pakraman village is a privilege for Hindus because of only those who can shape it and are given special funds from the local government for each Pakraman village.

\footnotetext{
${ }^{46}$ Suryawan, Genealogi Kekerasan Dan Pergolakan Subaltern: Bara Di Bali Utara, 1-4.

${ }^{47}$ Suryawan, Genealogi Kekerasan Dan Pergolakan Subaltern: Bara Di Bali Utara, 271.

${ }^{48}$ Syafrida Dea Irany, "Penyimpangan Sosial Yang Pernah Terjadi Di Desa Pegayaman," n.d., https://www.scribd.com/document/355363691/Penyimp angan-Sosial-Yang-Pernah-Terjadi-Di-Desa-

Pegayaman.

${ }^{49}$ Suryawan, Genealogi Kekerasan Dan Pergolakan Subaltern: Bara Di Bali Utara, 267.
}

Besides identity, another important issue is violence over religion's name (read: Islam). Although the violent actors are not Balinese Muslims, because of justification of Islamic doctrine on acts of terror and destruction as the implementation of jihad, Balinese Hindus' perception towards Muslims has also changed. It is shown by replacing the name nyame slam with jalma slam (Muslims) which means that the Balinese Hindu community no longer regards Muslims as "brothers" or at least there is a cold attitude displayed when communicating and interacting with Muslims. ${ }^{50}$ Bali Bombing I (2002) and Bali Bombing II (2005) cases are a series of very cruel terrorist acts, violence, and large-scale destruction. Both cases caused not only the destruction of the tourism economy but also many Muslim migrants who had to the exodus from Bali and break the knots of harmony between Muslims and Hindus in Bali. ${ }^{51}$ As the concern on negative excesses wide spreading of Bali Bombing case, AG. Ngurah Agung as Chairman of the Bali Muslim-Hindu Association often holds interfaith activities to restore Hindu-Muslim relations. It means that it is always necessary to have a proactive step between the two parties in weaving back the knot of togetherness, not blaming each other.

Bali Bombing case was one of the triggers for the birth of Hindu social prejudice against Balinese Muslims and migrants. ${ }^{52}$ This case has escalated Ajeg Bali movement which is interpreted in various ways, including Ajeg Bali is interpreted in a conservative-romantic perspective which is much influenced by Balinese indology. Here, Ajeg Bali is interpreted as Hindu Ajeg who considers Bali to return to dresta tradition that has long existed, considering that the changes occurred caused a serious threat to the integrity of

\footnotetext{
${ }^{50}$ Sahidin, interview by Mahmud Arif, Gelgel Village, on October 5, 2018.

${ }^{5}$ Sahidin, interview by Mahmud Arif, Gelgel Village, on October 5, 2018.

${ }^{52}$ Atmadja, Ajeg Bali: Gerakan, Identitas Kultural, Dan Globalisasi, 370.
} 
Balinese culture. ${ }^{53}$ Regional Regulation (Perda) No. 3/2001 which replaces Adat village with Pakraman village, for example, is increasingly establishing "Ajeg Hindu." Because through Pakraman village regulation, Balinese can get special privileges such as special funding from the local government outside the village funds. The formation of Pakraman village requires three things, namely (1) Parahyangan (temples and shrines for Hinduism), (2) Pawongan (Hindu villagers), and (3) Palemahan (village area). ${ }^{54}$ With these requirements, it is difficult for Muslims, who inhabit certain places including Pegayaman Muslim village, to form Pakraman village.

The existence of regulations and policies regarding Pakraman village is regarded as not only recognizing Hinduism as the majority religion of Balinese citizens but also placing it as a "first-class" entitled to privilege. After the Bali bombing, the regulations and policies regarding Pakraman village were considered reasonable as it was the last stronghold and a central actor in protecting Bali from terrorist and immigrant attacks. ${ }^{55}$ For Balinese Muslims, more or less the regulations and policies result in an atmosphere of mysticism that they are a minority group and the second class in the social hierarchy of citizenship in Bali. Such an atmosphere of mysticism is not ideal for realizing harmony between people of different religions in the framework of equality. However, maturity in citizenship has encouraged the Balinese Muslim community, especially Muslim citizens of Pegayaman village, not to perceive it as a form of social discrimination and injustice.

\section{CONCLUSION}

Bali exoticism lies not only on its natural beauty, artistic creativity and Hinduism with its rich ritual traditions but also the history of

\footnotetext{
${ }^{53}$ Suryawan, Genealogi Kekerasan Dan Pergolakan Subaltern: Bara Di Bali Utara, 263.

${ }^{54}$ Suryawan, Genealogi Kekerasan Dan Pergolakan Subaltern: Bara Di Bali Utara, 270.

${ }^{55}$ Suryawan, Genealogi Kekerasan Dan Pergolakan Subaltern: Bara Di Bali Utara, 270.
}

the Islamic minority with its cultural diversity and resilience. The development history of Islam has presented another side of Balinese exoticism because it is able to encourage the process of cultural acculturation, elevates local wisdom, and enriches cultural treasures, especially in the context of interfaith relations. As a leading tourist destination, Bali is always interesting to be visited and is the object of the study. However, the issue of relations among Islam, Hinduism, and Bali seems still give little attention from academics due to the frenetic influence of tourism. Naturally, the public is more familiar with Bali related to its various exotic tourist objects.

Islam is not a "migrant" religion; Islam is a religion adhered to by native Balinese. In the early Islamization process, Islam was spread by immigrants. However, over time, Islam also blends and integrates with the natures of Bali. As a famous tourist destination, Bali is flooded with migrants from various regions to settle down and earn a fortune, where some of them are Muslim. Although the level of success may not be as good as in Java, the long history of Islamization in Bali Island has been able to strengthen the development of Islam in certain enclaves, commonly called Muslim villages, such as Pegayaman Muslim village, Buleleng. This Muslim village has been formed hundreds of years ago, and it is very reasonable when they feel like a native of Bali. In the siege of the Hindu community majority, the Muslim community in the village managed to show its vitality, namely the ability to adapt dynamically and absorb selectively.

The position as the "oldest" village is realized by the Muslim community in Pegayaman village has long historical roots of harmonious relations among Islam, Puri (palace) and Hindus. This awareness encourages them not to forget themselves by denying the historical node of togetherness. The harmonious relationship among Islam, castle, and Hindus is a historical node of togetherness and at the same time the value of local wisdom that needs to be preserved through various social traditions such as the 
Maulid of the Prophet with ubo rampe sokok base, the use of distinctive Balinese names, the art of Sekee Burdah Burak Pegayaman group, and philosophy of Menyama Beraya, which is the context of historical articulation of Islam. Pegayaman village Muslim is a native of Bali and a Hindu (nyame slam). That is, Muslims and Hindus have a Balinese collective identity and mutual affinity of togetherness.

\section{REFERENCES}

Abadi, Moh Mashur. "Pesantren Desa Pegayaman, Meleburnya Jagat Bali Dalam Kearifan Islam." KARSA: Journal of Social and Islamic Culture 20, no. 1 (2012): 15264.

Agung, AAG. Putra. Peralihan Sistem Birokrasi Dari Tradisional Ke Kolonial. Yogyakarta: Pustaka Pelajar, 2009.

Antara. "Survei LIPI: Isu SARA Membesar Karena Dikapitalisasi Elit Politik." Antara News. Accessed August 12, 2018. https://www.antaranews.com/berita/734208 /survei-lipi-isu-sara-membesar-karenadikapitalisasi-elit-politik.

Atmadja, Nengah Bawa. Ajeg Bali: Gerakan, Identitas Kultural, Dan Globalisasi. Yogyakarta: LKiS, 2013.

- Genealogi Keruntuhan Majapahit: Islamisasi, Toleransi, Dan Pemertahanan Agama Hindu Di Bali. Yogyakarta: Pustaka Pelajar, 2010.

Burhanuddin, Yudhis M. Bali Yang Hilang: Pendatang, Islam Dan Etnisitas Di Bali. Yogyakarta: Impulse Kanisius, 2008.

Effendy, Bachtiar. Masyarakat, Agama Dan Pluralisme Keagamaan. Yogyakarta: Galang Press, 2001.

Fahham, A. Muchaddam. "Dinamika Hubungan Antarumat Beragama: Pola Hubungan Muslim Dan Hindu Di Bali." Aspirasi: Jurnal Masalah-Masalah Sosial 9, no. 1 (2018): 65-84.

Geertz, Clifford. Tafsir Kebudayaan \& Agama. Yogyakarta: Kanisius, 1992.

Irany, Syafrida Dea. "Penyimpangan Sosial Yang Pernah Terjadi Di Desa Pegayaman," n.d.

https://www.scribd.com/document/3553636 91/Penyimpangan-Sosial-Yang-Pernah-

Terjadi-Di-Desa-Pegayaman.

Karim, M. Abdul. "Toleransi UmaT Beragama Di Desa Loloan, JemBrana, Bali (Ditinjau Dari Perspektif Sejarah)." Analisis: Jurnal Studi Keislaman 16, no. 1 (2016): 1-32.

Kartini, Indriana. "Dinamika Kehidupan Minoritas Muslim Di Bali." Jurnal Masyarakat Indonesia 37, no. 2 (2011): 115-45.

Liliweri, Alo. Pengantar Studi Kebudayaan. Bandung: Nusa Media, 2014.

Martin Ramstedt. Kegalauan Identitas: Agama, Etnisitas Pada Masa Pascaorde Baru. Jakarta: Grasindo, 2011.

McGuire, Meredith B. Religion: The Social Context. California: Wadsworth Publishing, 1992.

Miharja, Deni. "Adat, Budaya Dan Agama Lokal: Studi Gerakan Ajeg Bali Hindu Bali." Kalam: Jurnal Studi Agama Dan Pemikiran Islam 7, no. 1 (2013): 53-78.

Mujiburrahman. Mengindonesiakan Islam. Yogyakarta: Pustaka Pelajar, 2008.

Nottingham, Elizabeth K. Agama Dan Masyarakat. Edited by terj. Abdul Muis Naharong. Jakarta: Rajawali Press, 1997.

Parimartha, I Gde, Ida Bagus Gde Putra, and Luh Pt. Kusuma Ririen. Bulan Sabit Di Pulau Dewata: Jejak Kampung Islam Kusamba-Bali. Edited by AAGN. Ari Dwipayana. Yogyakarta: CRCS UGM, 2012.

Potter, William J. An Analysis of Thinking and Research About Qualitative Methods. New Jersey: Lawrence Erlbaum Association, 1996.

Qurtuby, Sumanto Al. "Sejarah Politik Politisasi Agama Dan Dampaknya Di Indonesia." MAARIF Journal 13, no. 2 (2018): 43-54.

Republika. "Arya Wedakarna Curiga Masuknya Perbankan Syariah Di Bali." Republika. Accessed October 16, 2018. https://www.republika.co.id/berita/duniaislam/islam-nusantara/14/08/26/nawgoo- 
arya-wedakarna-curiga-masuknyaperbankan-syariah-di-bali.

Risakotta, Bernard A. Mengelola Keragaman Di Indonesia: Agama Dan Isu-Isu Globalisasi, Kekerasan, Gender, Dan Bencana Di Indonesia. Edited by Trans. Gunawan Admiranto dkk. Bandung: Mizan, 2015.

Suardi-Wekke, Ismail. "Sasi Masjid Dan Adat: Praktik Konservasi Lingkungan Masyarakat Minoritas Muslim Raja Ampat." Al-Tahrir: Jurnal Pemikiran Islam 15, no. 1 (2015): 120.

Suprapto. Semerbak Dupa Di Pulau Seribu Masjid. Jakarta: Kencana, 2010.

Suryawan, I Nyoman. Genealogi Kekerasan Dan Pergolakan Subaltern: Bara Di Bali Utara. Jakarta: Kencana, 2010.

Udasmoro, Wening. Dari Doing Ke Undoing Gender: Teori Dan Praktik Dalam Kajian Feminisme. Yogyakarta: Gadjah Mada University Press, 2017.
Wirutomo, Paulus. Sistem Sosial Indonesia. Jakarta: UI Press, 2012.

Yamin, Ade. "Menjadi Muslim Papua: Perjuangan Komunitas Dani Muslim Di Lembah Bailiem.” UMY, 2019.

Zuhro, R. Siti, Sumarno, Wenny Pahlemy, Nurul Rochayati, Lilis Mulyani, and Israr Iskandar. Demokrasi Lokal: Perubahan Dan Kesinambungan Nilai-Nilai Budaya Politik Lokal Di Jawa Timur, Sumatera Barat, Sulawesi Selatan Dan Bali. Yogyakarta: Ombak, 2009.

\section{INTERVIEW}

Nasrulloh, interview by Mahmud Arif. Gelgel Village. October 4, 2018.

Sahidin, interview by Mahmud Arif. Gelgel Village. October 5, 2018.

Suharto, Wayan, interview by Mahmud Arif. Gelgel Village. October 5, 2018.

Taidin, interview by Mahmud Arif. Gelgel Village. October 5, 2018. 